Aktualny nurt badań epigraficznych w historiografii Rzymu jest w tym wyborze rozpraw reprezentowany zwłaszcza przez teksty dotyczące specyfiki życia rodzinnego prowincji (m.in. A. Baziór, J. Hatłas, M. Žyromski). Przedstawione artykuły dają także możliwość konfrontacji wyników badań materialów z Mezji oraz Rzymu, a także analiz porównawczych rzeczywistości pogańskiej i chrześcijańskiej w ikonografii $i$ inskrypcjach (np. artykuly V. Rączewskiej oraz B. Stawoskiej-Jundziłł).

Problematykę rodziny chrześcijańskiej w starożytności oraz pismach Ojców Kościoła omawiają artykuły E. Gajdy, J. Iluka, W. My- szora, M. Kosznickiego. Ta grupa rozpraw prezentuje dyskusje nad ideałami a stanem małżenstwa i rodziny wprowadzoną do tematyki czasów cesarstwa rzymskiego przez chrześcijańską naukę społeczną

Zamykające zbiór artykuły J. Woźnego oraz M. Cholodowskiej rozszerzaja zagadnienia sygnalizowane w tytule tomu, ale jednoczesnie stanowią przyczynek do studiów komparatystycznych nad zebranym materiałem.

Książka ukazała się nakładem Wydawnictwa Wyższej Szkoły Pedagogicznej w Bydgoszczy.

Aldona Ossowska

\title{
Stan i perspektywy historii wychowania, red. W. Jamrożek, Poznań 1995, Wydawnictwo Eruditus
}

Prezentowane w książce teksty s̨̨ owocem ogólnopolskiej konferencji naukowej, która odbyła się w dniach 18-20 października 1994 roku w Obrzycku (w Domu Pracy Twórczej i Wypoczynku Uniwersytetu im. Adama Mickiewicza). Została ona zorganizowana przez Zakład Historii Wychowania UAM i Sekcje Historii Wychowania Polskiego Towarzystwa Pedagogicznego.

Tematyka konferencji dotyczyła, ujmując najogólniej, stanu oraz perspektyw historii wychowania jako swoistej dyscypliny naukowej i jako przedmiotu nauczania w szkole wyższej. Zamieszczone w książce wystąpienia stanowią pewnq egzemplifikację formulowanych podczas tego spotkania opinii, jak i prezentacji wyników badań, przedstawiając zarazem - przynajmniej w przybliżeniu - przebieg obrad i dyskusji (wiele wystąpień, prezentowanych zwłaszcza w zespołach roboczych, nie było wcześniej przygotowanych i do końca nie przybrało formy pisemnej). Zostały one opublikowane w ramach trzech zasadniczych części problemowych, tak jak w większości były prezentowane na konferencji: tendencje i kierunki badawcze historii wychowania - jako dyscypliny naukowej (tek- sty Danuty Dryndy, Agnieszki Stopińskiej-Pajak, Władysławy Szulakiewicz, Jana Hellwiga), problemy warsztatu badawczego historyka wychowania (wystąpienia Czesława Majorka, Wiesława Ciczkowskiego, Sławomira Sztobryna, Stefanii Walasek), zagadnienia dydaktyki historii wychowania (teksty Wiesława Jamrożka, Krzysztofa Jakubiaka, Juliusza Jundziłła, Anny Walczak, Edyty Bartkowiak, Ilony Błaszczyk, Alicji Kicowskiej, Elżbiety Magiery, Ryszarda Ślęczki). Ostatnia (czwarta) część książki zawiera materiały stanowiące jakby swoiste pođsumowanie wyników konferencji i zastępuje tradycyjne „zakończenie” (tekst Jolanty Szablickiej-Żak, głos Jana Hellwiga na zamknięcie konferencji oraz informacja o autorach).

Praca adresowana jest głównie do osób interesujących się bliżej problematyka teorii i metodologii oraz dydaktyki historii wychowania, w szczególności do badaczy dziejów wychowania młodszej generacji, dla której może ona stanowić także cenny przykład wymiany doświadczeń naukowych $i$ dydaktycznych.

$($ Red.) 